\title{
Joint Action of Entomopathogenic Fungus Beauveria bassiana and Certain Indigenous Products against Plutella Xylostella (Linn) Infesting Cabbage
}

\author{
A.K. Rai ${ }^{1}$, Kamin Alexander ${ }^{2 *}$ and O.P. Verma ${ }^{3}$ \\ ${ }^{1}$ Department of Agricultural Economics and Statistics, Kul Bhaskar Ashram Post Graduate \\ College, Prayagraj, India \\ ${ }^{2}$ Department of Biological Sciences, Sam Higginbottom University of Agriculture, Technology \\ \& Sciences, Prayagraj, India \\ ${ }^{3}$ Department of Molecular and Cellular Engineering, SHUATS, India \\ *Corresponding author
}

\section{A B S T R A C T}

\section{Keywords}

Beauveria bassiana, Indigenous products, Cabbage, Plutellaxyloslella

Article Info

Accepted:

04 June 2019

Available Online:

10 July 2019
The present study was conducted to know the comparative efficacy of Entomopathogenic fungus Beauveria bassiana and certain indigenous products against the larvae of diamond back moth, Plutella xylostella (Linn) on Cabbage (Brassica oleracea) a lab trial was conducted during the 2017-2018 at SHUATS, Allahabad. All the treatments were found significantly superior over control. Among the treatments the highest larval mortality of $100 \%$ with the treatment $\mathrm{T}_{4}$ and the minimum larval mortality of $26.666 \%$ was recorded with the treatment $\mathrm{T}_{2}(\mathrm{NL}+\mathrm{BBM})$. Each treatment was replicated three times and mortality of different larval instar $\left(1^{\text {st }}, 3^{\text {rd }}\right.$, $5^{\text {th }}$ ) was recorded after. 24,48 and 72 hours, mortality at 72 hours was highest over 48 and 24 hours and mortality in $1^{\text {st }}$ instar was found more in comparison to $3^{\text {rd }}$ and $5^{\text {th }}$ instar.

\section{Introduction}

Cabbage (Brassica Oleracea Var. Capitata) is one of the most important cruciferous vegetable grown all over the country with 0.27 million hector areas and 5.90 million tones production. Among the pest complex of cabbage, diamond back moth (DBM) Plutella Xylosletta (Linn) is the most destructive and dreaded Pest. It was reported that52 percent loss in marketable yield of cabbage due to attack of Plutella xylostella (Krishna Kumar, 1983). Indigenous products Viz. Neem products are not only effective against the crop pest but also ecologically safe and free from residual problems. Neem oil $1 \%$ water extract of neem leaves- $40 \%$ and neem kernel extract-2\% have been found effective against bridjly in linseed (Gupta et al., 2000) and so, attention is now being focused on the use of biopesticides, Beauveria bassiana Constituting on the important component to 
supplement or as on alternate to synthetic chemicals. Keeping these facts in view, present study were conducted to evaluate the efficacy of Indigenous products and Entomopathogenic fungus Beauveria bassiana against Plutella Xylostella under laboratory condition.

\section{Materials and Methods}

The trial was carried out for the management of Plutella Xylostella at the Department of Biological Sciences, SHUATS, Prayagraj for deterning the efficacy of different treatments against the $\mathrm{I}^{\text {st }}$ instar, $3^{\text {rd }}$ instar and $5^{\text {th }}$ instar larvae. The larvae of Plutella Xylostella (Linn.) were kept in Jar $(6 \times 8$ inch) covered by muslin cloth. The insect were fed on fresh capable leaves at $28+2^{\circ} \mathrm{C}$ and $70-80 \%$ R.H. Laboratory culture of Plutella Xylostella, was maintained on excised leaves of cabbage as per the method elaborated by standard methods (Sood et al., 1996). There were 11 treatment including control.

\section{Details of this treatment}

$\mathrm{T}_{1}$-Neem leaf + Buffalo Urine $4 \%$

$\mathrm{T}_{2}$-Neem leaf + Buffalo Butter Milk 4\%

$\mathrm{T}_{3}$-NSKE + Buffalo Butter Milk 4\%

$\mathrm{T}_{4}$-D.D.V.P. $0.05 \%$

$\mathrm{T}_{5}$-D.D.V.P. $0.25 \%+$ Beauveriabassiana $2 \%$

$\mathrm{T}_{6}$ - D.D.V.P. $0.025 \%+$ Beauveriabassiana $4 \%$

$\mathrm{T}_{7}$ - D.D.V.P. $0.025 \%+$ Neem leaf + Buffalow Butter Milk 2\%

T8- D.D.V.P. $0.025 \%+$ Neem leaf + Buffalo Urine $2 \%$

T9.D.D.V.P. 0.025\%+NSKE+ Buffalo Butter Milk 2\%
T10-D.D.V.P. $0.025 \%$ + N.S.K.E. + Buffalow Urine $2 \%$

$\mathrm{T}_{0}$-Control (D.W.)

\section{Results and Discussion}

The data on efficacy of Indigenous product applied in combination with insecticide in the control of larvae Plutella Xylostella are presented in the Table 1,2 and 3.

In the present study, the mortality of Spodopteralitura was significantly more by $\mathrm{T}_{4}$ (DDVP $0.05 \%$ ) was found to be superiors in larval. Population reduction followed by $\mathrm{T}$ ${ }_{6}>T_{5}>T_{10}>T_{9}>T_{3}>T_{1}>T_{2}$. The mortality in $1^{\text {st }}$ instar larval is significantly more over $3^{\text {rd }}$ and $5^{\text {th }}$ instar larvae and mortality at 72 hours was highest over $48 \mathrm{hrs}$ and $24 \mathrm{hrs}$.

The results of the present study corraborate the finding of (Aggarwal, 1990; Ali- Niazee et al., 1997; Bhalla et al., 1991; Schmutterce, 1990; Verma et al., 1994). They reported that younger instars were more susceptible to HNSKE than older one of S.litura Combined effect of BTK and SINPV with of S. lituraon cauliflower (Masuda, 2001; Srinivasan, 2004; Sood et al., 1996). Yoon et al., (1999) also reported the efficacy of mixture of insecticides. The treatment of DDVP solution recorded highest mortality $100 \%$ on I, III, V instar larvae at $72 \mathrm{hrs}$, Application of treatments was done by leaf dip or larval feeding $T_{1}>T_{2}>T_{0}$ and the order of mortality recorded was as $1^{\text {st }}>3^{\text {rd }}>5^{\text {th }}$ instar.

\section{Acknowledgement}

The authors are thankful to the Head, Department of Biological Sciences, SHUATS, for extending facility during the courses of investigation technique (Poison food technique) and the order of mortality due to treatments was as $T_{4}>T_{6}>T_{5}>T_{10}>T_{9}>T_{3}>$ 
Table.1 Effect of different Treatment on $1^{\text {st }}, 3^{\text {rd }}, 5^{\text {th }}$ instar larvae of Plutella xylostella when treated for 24 hours through leaf dip method

\begin{tabular}{|c|c|c|c|c|c|c|}
\hline \multirow[t]{2}{*}{ Treatment } & \multicolumn{2}{|c|}{$1^{\text {st }}$ instar } & \multicolumn{2}{|c|}{$3^{\text {rd }}$ instar } & \multicolumn{2}{|c|}{$5^{\text {th }}$ instar } \\
\hline & $\%$ mortality & $\%$ net mortality & $\%$ mortality & \%net mortality & $\%$ mortality & $\%$ net mortality \\
\hline T1 & 46.666 & 42.857 & 33.333 & 28.571 & 30.000 & 25.000 \\
\hline $\mathbf{T} 2$ & 40.00 & 35.714 & 30.000 & 25.00 & 26.666 & 21.429 \\
\hline T3 & 50.000 & 46.429 & 46.666 & 42.857 & 46.666 & 42.857 \\
\hline T4 & 100.000 & 100.000 & 96.666 & 96.429 & 96.666 & 96.429 \\
\hline T5 & 76.666 & 75.000 & 70.000 & 67.857 & 70.000 & 67.857 \\
\hline T6 & 80.000 & 78.571 & 76.666 & 75.000 & 76.666 & 75.000 \\
\hline T7 & 63.333 & 60.714 & 60.000 & 57.143 & 56.666 & 53.571 \\
\hline T8 & 63.333 & 60.714 & 63.333 & 60.724 & 60.000 & 57.143 \\
\hline T9 & 56.666 & 53.571 & 53.333 & 50.000 & 53.333 & 50.00 \\
\hline T10 & 70.000 & 67.857 & 66.666 & 64.296 & 63.333 & 60.714 \\
\hline T0 & 6.666 & 0.000 & 6.666 & 0.000 & 6.6666 & 0 \\
\hline Mean & 58.72 & (56.49) & 54.84 & (51.62) & 53.32 & (49.88) \\
\hline
\end{tabular}

Table.2 Effect of different Treatment on $1^{\text {st }}, 3^{\text {rd }}, 5^{\text {th }}$ instar larvae of Plutella xylostella when treated for 48 hours through leaf dip method

\begin{tabular}{|c|c|c|c|c|c|c|}
\hline \multirow[t]{2}{*}{ Treatment } & \multicolumn{2}{|c|}{$1^{\text {st }}$ instar } & \multicolumn{2}{|c|}{$3^{\text {rd }}$ instar } & \multicolumn{2}{|c|}{$5^{\text {th }}$ instar } \\
\hline & $\%$ mortality & $\%$ net mortality & $\%$ mortality & $\%$ net mortality & $\%$ mortality & $\%$ net mortality \\
\hline T1 & 50.000 & 46.421 & 40.00 & 35.714 & 36.666 & 32.143 \\
\hline T2 & 43.333 & 39.289 & 40.00 & 35.714 & 33.333 & 28.571 \\
\hline T3 & 53.333 & 50.00 & 50.00 & 46.421 & 46.666 & 42.857 \\
\hline T4 & 100.00 & 100.00 & 100.00 & 100.00 & 100.00 & 100.000 \\
\hline T5 & 76.666 & 75.000 & 73.333 & 71.429 & 70.000 & 67.857 \\
\hline T6 & 83.333 & 82.142 & 80.000 & 78.571 & 76.666 & 75.0000 \\
\hline T7 & 63.333 & 60.000 & 60.000 & 57.143 & 56.666 & 53.571 \\
\hline T8 & 70.00 & 714 & 60.000 & 57.143 & 60.000 & 57.143 \\
\hline T9 & 60.00 & 67.857 & 56.666 & 53.571 & 53.333 & 50.000 \\
\hline T10 & 73.333 & 57.143 & 66.666 & 64.286 & 63.333 & 60.714 \\
\hline T0 & 6.666 & 0.00 & 6.666 & 0.00 & 6.666 & 0.000 \\
\hline Mean & 61.81 & 59.29 & 57.67 & 53.56 & 54.84 & 51.534 \\
\hline
\end{tabular}


Table.3 Effect of different Treatment on $1^{\text {st }}, 3^{\text {rd }}, 5^{\text {th }}$ instar larvae of Plutella xylostella when treated for 72 hours through leaf dip method

\begin{tabular}{|c|c|c|c|c|c|c|}
\hline \multirow[t]{2}{*}{ Treatment } & \multicolumn{2}{|c|}{$1^{\text {st }}$ instar } & \multicolumn{2}{|c|}{$3^{\text {rd }}$ instar } & \multicolumn{2}{|c|}{$5^{\text {th }}$ instar } \\
\hline & $\%$ mortality & $\%$ net mortality & $\%$ mortality & $\%$ net mortality & $\%$ mortality & \% net mortality \\
\hline $\mathbf{T 1}$ & 53.333 & 50.000 & 50.000 & 46.429 & 43.333 & 39.286 \\
\hline $\mathbf{T 2}$ & 46.666 & 42.857 & 46.666 & 42.857 & 43.333 & 39.286 \\
\hline T3 & 60.000 & 57.143 & 56.666 & 53.571 & 50.000 & 46.429 \\
\hline T4 & 100.000 & 100.000 & 100.00 & 100.00 & 100.00 & 100.00 \\
\hline T5 & 83.333 & 82.143 & 76.666 & 75.000 & 73.333 & 71.429 \\
\hline T6 & 86.6666 & 85.714 & 83.333 & 82.143 & 83.333 & 82.143 \\
\hline T7 & 66.666 & 63.296 & 63.333 & 60.714 & 63.333 & 60.714 \\
\hline T8 & 76.666 & 75.000 & 73.333 & 71.429 & 66.666 & 64.286 \\
\hline T9 & 63.3333 & 60.714 & 60.333 & 57.143 & 56.666 & 53.571 \\
\hline T10 & 80.000 & 78.571 & 73.333 & 71.429 & 70.000 & 67.857 \\
\hline T0 & 6.6666 & 0.000 & 6.666 & 0.000 & 6.666 & 0.000 \\
\hline Mean & 75.57 & 69.70 & 62.75 & 55.81 & 59.66 & 52.85 \\
\hline
\end{tabular}




\section{References}

Aggarwal, G.P. Entomogenous fungi in India and Management of Insect pest. Indian Phytopathology. 1990; 43 (2): 131-142.

Ali- Niazee, M.T., Alhumeyri, A. and Saeed, M. Laboratory and field evaluation of wem insecticide against Archipsrosanus L. (Lepidoptera; Torticidae). The Conadian Entomologist. 1997; 129: 27 33.

Bhalla, O.P., and Verma, A.K. Integrated Pest Management studies on cauliflower and cabbage in temperate regions of Himachal Pradesh. Final Report of Adhoe Research Project submitted to ICAR, New Delhi.1991.

Gupta, M.P., Chaurasia, S.K. and Rai, H.S. Efficacy of neem plant products against the budfly (Dasineurs Lini) on linsee, Indian J. Agric. Sci., 2000; 70: 762764.

Krishna Kumar, H.K., Srinivasan, K., and Suman, C.L. Optimum Control Strategy of Cabbage pests from a Chemical Control Trial. Prog. Most, 1983; 18: 104-110.

Masuda, T. Microbial Control of diamond back moth, Plutella xylostella by entomopathogenic fungus: Beauveria bassiana Laboratory studies on pathogenicity of Beauveria bassiana and field experiment: Japanese J. Appl. Ent. 2001; 42 (2): 51-58.

Schmutterce, H. Properties and Potential of Natural pesticides from neem tree, Azadirachtaindica. A. Review Entomdogy, 1990; 35: 217-297.

Sood, A.K., Chauhan, V. and Bhalla, O.P. Laboratory rearing technique of the diamond back moth, Plutella xylostella (L) and the effect of host species on its development. Post. Mgt. Econ. Zool, 1996; 4 (192): 81-84

Srinivasan, G. and Sundara Babu, P.C. Field evaluation of neem products against white ply on brinjal. Ann. Pl. Protec. Sci., 2004; 9: 19-21.

Verma, A.K., Sood, A.K. and Bhella, O.P. Seasonal abundance and management of cabbage pests in Himachal Pradesh, National Symposium on Emerging trends in Pest Management: University of Horticulture and Forestry. Solan: June 28-30, 1994; 21-22.

Yoon, C.S., Sung, G.H., Park, H.S., Lec, S.G. and Lec, S.O. Potential bassiana strain CS-I as a biological control agent of Plutella xylostella (Lep. Xpanomentidae), J. Appl. Ent. 1999; 123 (7): 423- 425.

\section{How to cite this article:}

Rai, A.K., Kamin Alexander and Verma, O.P. 2019. Joint Action of Entomopathogenic Fungus Beauveria bassiana and Certain Indigenous Products against Plutella Xylostella (Linn) Infesting Cabbage. Int.J.Curr.Microbiol.App.Sci. 8(07): 254-258.

doi: https://doi.org/10.20546/ijcmas.2019.807.032 